\title{
Soil compaction response to wheel traffic in the Rolling Pampas region of Argentina
}

\section{Respuesta de la compactación del suelo al tráfico de ruedas en la Región de la Pampa ondulada de Argentina}

Enrique Ernesto Contessotto ${ }^{1}$, Guido Fernando Botta ${ }^{1}$, Marcos Esteban Angelini ${ }^{2}$, Fernando Bienvenido ${ }^{3}$, David Rivero ${ }^{4}$, Federico Matías Pelizzari ${ }^{4}$, Diego Gabriel Ghelfi ${ }^{1}$, Ayelén Ileana Nistal ${ }^{1}$

Originales: Recepción: 10/03/2021 - Aceptación: 16/04/2021

\section{Abstract}

The present work shows the effects of the different agricultural wheels traffic on the physical properties of a typical Argiudol soil worked under a no-tillage cropping system. Soil compaction produced by traffic was quantified through a series of parameters. These parameters were: a) cone index, b) rut depth and c) soil water content at the traffic moment. A grain chaser, a sprayer, a combine harvester and a tractor equipped with commonly used wheels were tested in the study area. The main results obtained showed that the tyres with the highest inflation pressure and tyre ground pressures produced the highest values of cone index and rut depth. A typical Argiudol soilis not able to constrain topsoil and subsoil compaction when wheeled by tyres with ground pressures greater than $77.6 \mathrm{kPa}$. This occurs when this soil is worked under a continuous no-tillage cropping system.

\section{Keywords}

tyre inflation pressure $\bullet$ cone index $\bullet$ soil bearing capacity

1 Universidad Nacional de Luján. Ruta 5 y Avenida Constitución. Luján. C.P 6700. Provincia de Buenos Aires. Argentina. eecontessotto@gmail.com

2 INTA. CIRN. Instituto de Suelos. De los Reseros y N Repetto s/n. Hurlingham. C.P. 1636. Provincia de Buenos Aires. Argentina.

3 Universidad de Almería. Ctra. Sacramento s/n. La Cañada de San Urbano. 04120. Almería. España.

4 Universidad Nacional de La Pampa. Facultad de Agronomía. Ruta 35 - Km 334 Santa Rosa. C. P. 6300. Provincia de La Pampa. Argentina. 


\section{RESUMEN}

En el presente trabajo se muestran los efectos del tránsito de diferentes ruedas agrícolas sobre las propiedades físicas de un suelo Argiudol Típico trabajado bajo el sistema de no-labranza. La compactación del suelo producida por el tráfico se cuantificó a través de los parámetros: a) índice de cono, b) profundidad de huella y c) contenido de agua del suelo al momento del tránsito. Se ensayaron carro de granos, cosechadora, pulverizadora y tractor equipados con rodados de uso generalizado en la zona productiva bajo estudio. Los principales resultados obtenidos demostraron que los neumáticos con mayor presión de inflado y presión en el área de contacto rueda/suelo produjeron los mayores valores de índice de cono y profundidad de huella. El suelo Argiudol típico trabajado en forma continua bajo no-labranza no puede limitar la compactación superficial y subsuperficial del suelo cuando es transitado por ruedas con presiones en el área de contacto rueda/suelo mayores a $77.6 \mathrm{kPa}$.

\section{Palabras clave}

presión de inflado • índice de cono • capacidad portante del suelo

\section{INTRODUCTION}

According to the European Soil Framework Directive (2006), compaction, in addition to water and wind erosion, is one of the main causes of soil degradation. It has been estimated that more than half of the world's eroded area is caused by soil compaction and soil deformation. As a matter of fact, soil compaction and soil deformation are produced by incorrect soil management. Traffic compaction has adverse effects on the physical, chemical and biological properties of soil. This affects important soil processes and functions that govern the crop productivity (2).

Soil compaction causes a reduction in root growth and yield in many crops. Botta et al. (2004) applied $4 \mathrm{Mg}$ tractor traffic in a field where a wheat-soybean double cropping rotation under no-tillage had been practised for seven years. Traffic was applied at intensities of 60 to $180 \mathrm{Mg} \mathrm{km} \mathrm{ha}^{-1}$. This treatment caused soil compaction up to $600 \mathrm{~mm}$ depth. As a result, there was a decrease in yield of the following soybean crop from $9.8 \%$ to $38 \%$, respectively. Besides, Canarache et al. (1984) found that for each $1 \mathrm{~kg} / \mathrm{m}^{3}$ increase in bulk density in Romanian soils, a decrease in maize grain yields was $18 \%$ relative to the yield in a non-compacted plot.

According to Raper (2005), soil deterioration produced by agricultural traffic can sometimes be visible above-ground as soil deformation or it can be hidden below-ground. In either case, agricultural traffic can reduce crop production by causing a compacted soil condition that is not compatible with plant growth. Traffic-induced compaction in the subsoil (below $200 \mathrm{~mm}$ in our case) tends to be cumulative. This is because standard tillage operations are rarely performed at depths greater than about $25-30 \mathrm{~cm}(6,17)$.

Compaction is caused by the high wheel loads and tyre ground pressures exerted on the soil by the tires of machinery used in no-tillage crop operations. Special emphasis should be placed on the impact of these operations when performed on wet clay soils or with high tire inflation pressure (between 140 and $218 \mathrm{kPa}$ ) (10).

It is difficult to generalise, globally, however there is a growing knowledge base that random traffic operations with heavy machinery on moist soil causes soil compaction specifically, and more generally, reductions in water use and fertiliser efficiencies and crop productivity, and off-site environmental problems particularly from increased runoff (26).

Threadgill (1982) noted that soils with a CI $>1.5$ MPa reduced root growth. In this regard, when soils are compacted with $\mathrm{CI}$ values higher than $2 \mathrm{MPa}$, the roots of most annual crops practically stop growing (7).

There are a number of techniques commonly utilized for the control and management of topsoil and subsoil compaction. These techniques are subsoiling and chiseling, controlled traffic farming (CTF), seasonal controlled traffic farming (SCTF) and axle load reduction (2). Deep soil compaction remediation can prove impractical, and often uneconomical, at depths greater than about $400-\mathrm{mm}(9,15,18,24,25)$. 
Note that permanent traffic lanes represent full adoption of the CTF. On the other hand, the SCTF refers to temporary tracks, where affected areas may be targeted for post-harvest remediation. Regarding the SCTF, Vermeulen and Mosquera (2009) found that the mean total and air-filled porosity at $10 \mathrm{kPa}$ of topsoil water matric pressure increased on average from 0.468 to 0.492 and from 0.132 to 0.166 , respectively. This was observed in comparison to the random traffic system for crops grown in a field study between 2002 and 2005 . They also found that crop yields increased significantly by $31 \%$ in green peas in 2002 , by $15 \%$ in spinach in 2004 and by $10 \%$ in planted onion sets in 2005 . On the other hand, no differences were observed in carrot and sown onion when the SCTF system was used instead of the random traffic system.

The work presents two objectives. The first objective was to evaluate the effect of wheel traffic on the soil physical properties of a typical Argiudol soil in the Rolling Pampas region of Argentina. The second objective was to study the traffic layout in different agricultural tasks to reduce compaction in a soil under a continuous no-tillage cropping system. Our hypothesis was that, in a soil under a continuous no-tillage cropping system, compaction mitigation may be achieved by operating with low-loads, low contact pressure from tyres and reducing the trampled area.

\section{MATERIALS AND METHODS}

\section{The site}

The experiment was conducted in the east of the Rolling Pampa region, Buenos Aires State, Argentina. The soil is a typical Argiudol (22) worked under a no-tillage system. The soil physical and mechanical properties are given in table 1.

Table 1. Typical Argiudol soil profile characteristics.

Tabla 1. Características del perfil del suelo Argiudol típico.

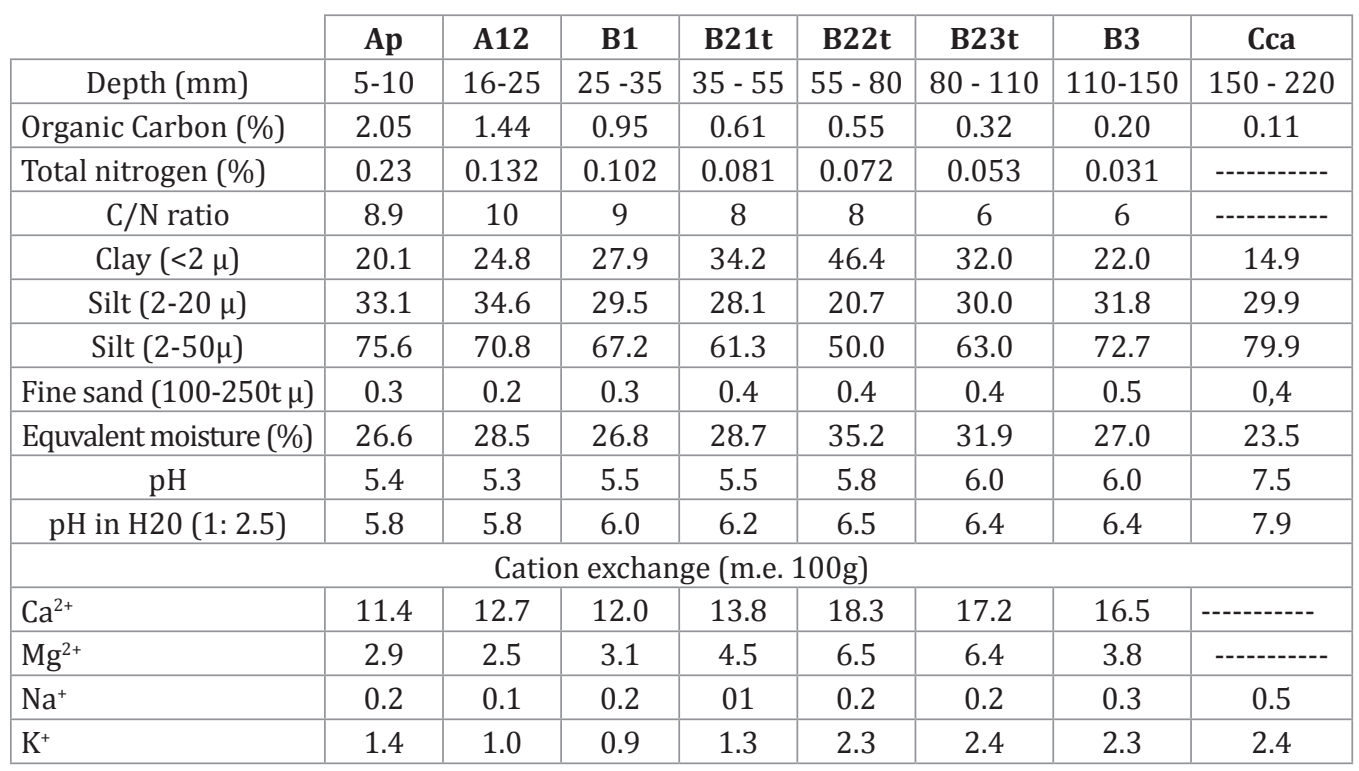

\section{Treatments}

We performed five treatments. One of these treatments was used as a control with no traffic. The remaining four treatments were carried out with machines that had different tyre ground pressures. The modification of each treatment is determined by the agricultural machine and the tyre to be used respectively. Description of the machinery used is given in table 2 (page 112). The real work speed was calculated with the distance / time equation for each labour. The time the equipment took to travel $75 \mathrm{~m}$ of each plot was recorded. 
Table 2. Characteristics of the machinery used in the trial.

Tabla 2. Características de la maquinaria usada en el ensayo.

\begin{tabular}{|c|c|c|c|}
\hline \multicolumn{2}{|l|}{ Tractor FWA } & \multicolumn{2}{|l|}{ Grain chaser (Two axle and single wheels) } \\
\hline $\begin{array}{l}\text { Engine power }(\mathrm{CV} / \mathrm{kW}) \\
\text { Front tyres } \\
\text { Rear tyres } \\
\text { Inflation pressure, front tyre }(\mathrm{kPa}) \\
\text { Inflation pressure, rear tyre }(\mathrm{kPa}) \\
\text { Overall weight }(\mathrm{kN}) \\
\text { Front weight }(\mathrm{kN}) \\
\text { Rear weight }(\mathrm{kN}) \\
\text { Static load per front wheel }(\mathrm{kN}) \\
\text { Static load per rear wheel }(\mathrm{kN}) \\
\text { Mean ground pressure per for front tyre }(\mathrm{kPa}) \\
\text { Mean ground pressure per rear tyre }(\mathrm{kPa}) \\
\text { Distance between the tyres of the tractor and } \\
\text { tyres of the grain chaser }(\mathrm{mm})\end{array}$ & $\begin{array}{l}145 / 106.7 \\
16.9 \text { R } 26 \\
24.5 \text { R } 32 \\
70 \\
65 \\
79.80 \\
31.75 \\
48.05 \\
15.875 \\
24.025 \\
37.63 \\
40.02 \\
\\
3.380\end{array}$ & $\begin{array}{l}\text { Front tyres } \\
\text { Rear tyres } \\
\text { Inflation pressure, front tyre }(\mathrm{kPa}) \\
\text { Inflation pressure, rear tyre }(\mathrm{kPa}) \\
\text { Overall weight loaded }(\mathrm{kN}) \\
\text { Front weight }(\mathrm{kN}) \\
\text { Rear weight }(\mathrm{kN}) \\
\text { Static load per front wheel }(\mathrm{kN}) \\
\text { Static load per rear wheel }(\mathrm{kN}) \\
\text { Mean ground pressure per for front tyre }(\mathrm{kPa}) \\
\text { Mean ground pressure per rear tyre }(\mathrm{kPa})\end{array}$ & $\begin{array}{c}24.5 \text { R } 32 \\
24.5 \text { R } 32 \\
120 \\
120 \\
196 \\
98 \\
98 \\
49 \\
49 \\
77.6 \\
78.7\end{array}$ \\
\hline Combine Harvester & & Sprayer & \\
\hline $\begin{array}{l}\text { Engine power }(\mathrm{CV} / \mathrm{kW}) \\
\text { Front tyres } \\
\text { Front tyres inflation pressure }(\mathrm{kPa}) \\
\text { Rear tyres } \\
\text { Rear tyres inflation pressure }(\mathrm{kPa}) \\
\text { Total weight loaded }(\mathrm{kN}) \\
\text { Front axle weight }(\mathrm{kN}) \\
\text { Rear axle weight }(\mathrm{kN}) \\
\text { Static load per front wheel }(\mathrm{kN}) \\
\text { Static load per rear wheel }(\mathrm{kN}) \\
\text { Mean ground pressure per front tyre } \mathrm{kPa}) \\
\text { Mean ground pressure per rear tyre }(\mathrm{kPa}) \\
\text { Hedaer width }(\mathrm{m})\end{array}$ & $\begin{array}{c}255 / 187 \\
600 / 70 \mathrm{R} 30 \\
140 \\
11.25-24 \\
145 \\
152.5 \\
103.7 \\
48.8 \\
51.85 \\
24.4 \\
135 \\
198 \\
7\end{array}$ & $\begin{array}{l}\text { Engine power }(\mathrm{CV} / \mathrm{kW}) \\
\text { Front tyres } \\
\text { Front tyres inflation pressure }(\mathrm{kPa}) \\
\text { Rear tyres } \\
\text { Rear tyres inflation pressure }(\mathrm{kPa}) \\
\text { Total weight loaded }(\mathrm{kN}) \\
\text { Front axle weight }(\mathrm{kN}) \\
\text { Rear axle weight }(\mathrm{kN}) \\
\text { Static load per front wheel }(\mathrm{kN}) \\
\text { Static load per rear wheel }(\mathrm{kN}) \\
\text { Mean ground pressure per front tyre } \mathrm{kPa}) \\
\text { Mean ground pressure per rear tyre }(\mathrm{kPa}) \\
\text { Sprayer boom width }(\mathrm{m})\end{array}$ & $\begin{array}{c}142 / 104 \\
12.4-36 \\
285 \\
12.4-36 \\
285 \\
108.7 \\
43.48 \\
65.22 \\
21.74 \\
32.61 \\
233 \\
254 \\
21\end{array}$ \\
\hline
\end{tabular}

The treatments were settled in plots of $100 \mathrm{~m}$ long by $20 \mathrm{~m}$ wide $\left(2000 \mathrm{~m}^{2}\right)$, in four completely randomized replications plots (figure 1, page 113). A buffer zone of $10 \mathrm{~m}$ between plots was established according to the proposal of Maineri (2020).

The mean ground contact pressure (GCP) of the machines was measured with a Tekscan device. Tyre inflation pressures were adjusted according to the tyre manufacturers' recommendations for the load and the operation speed. Note that the soil water content (SWC) at the traffic moment was near but below the field capacity.

\section{Parameters monitored}

Cone index (CI), soil water content (SWC) and rut depth (RD) were measured on the same day as the traffic treatments were applied. The parameters (CI, SWC and RD) were measured along the central $50 \mathrm{~m}$ of each plot. The CI was measured with a recording penetrometer (4) and the procedure according to ASABE (2013). The average of 25 samples was taken as the datum for each plot at a depth range of $0-450 \mathrm{~mm}$, measured at $25 \mathrm{~mm}$ depth intervals. The SWC was estimated according to Botta et al. (2002). The RD was measured using a profile meter consisting of a set of vertical metal rods of $700 \mathrm{~mm}$ long and $5 \mathrm{~mm}$ in diameter. These rods were spaced at $25 \mathrm{~mm}$ horizontal intervals, sliding through holes in a 1-m long iron bar. The bar was placed across the removed soil perpendicular to the direction of travel and the rods were positioned to conform to the shape of the depression. The removed area was calculated as the average depth of 20 reads on the $1-\mathrm{m}$ bar.

\section{Explanatory variables}

The trampled area (TA) by agricultural machinery was determined using a PCS-215 Pentax total station. Finally, the maximum bulk density (BD) and the critical soil water content (SWC) were determined according to the standard Proctor method (5) described by Botta et al. (2012). 


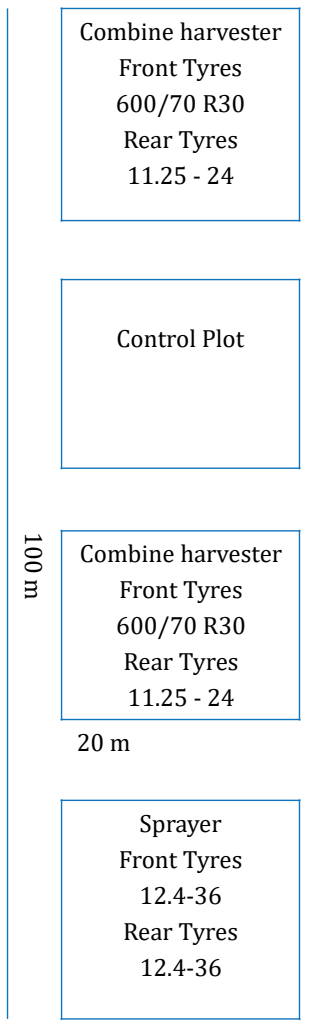

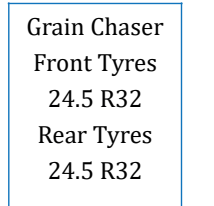
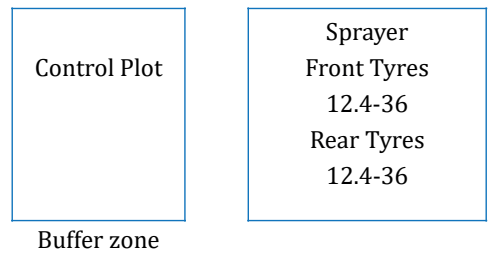

FWA Tractor

Front Tyres

16.9 R26

Rear Tyres

24.5 R32

Buffer zone

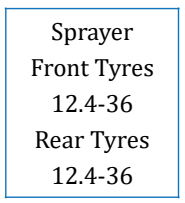

\begin{tabular}{|c|}
\hline FWA Tractor \\
Front Tyres \\
16.9 R26 \\
Rear Tyres \\
24.5 R32 \\
\hline
\end{tabular}

Combine harvester

Front Tyres

600/70 R30

Rear Tyres

11.25 - 24

Buffer zone

\section{FWA Tractor}

Front Tyres

16.9 R26

Rear Tyres

24.5 R32

\begin{tabular}{|c|}
\hline Grain Chaser \\
Front Tyres \\
24.5 R32 \\
Rear Tyres \\
24.5 R32 \\
\hline
\end{tabular}

Buffer zone

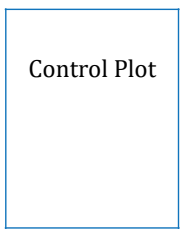

\begin{tabular}{|c|} 
FWA Tractor \\
Front Tyres \\
16.9 R26 \\
Rear Tyres \\
24.5 R32
\end{tabular}

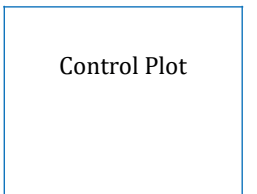

Sprayer

Front Tyres

12.4-36

Rear Tyres

12.4-36

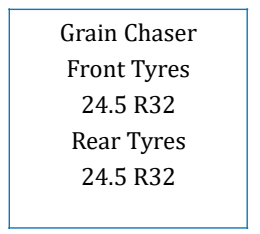

Combine harvester Front Tyres 600/70 R30 Rear Tyres $11.25-24$

Figure 1. Experimental design. / Figura 1. Diseño experimental.

\section{Statistical analyses}

Statistical analyses were performed by the Statgraf program 7.1. An analysis of variance (ANOVA) was carried out and means were analyzed by Duncan's multiple range test. A priori we confirmed that the soil data followed a normal distribution, according to the Shapiro-Wilk test. When checking the normality of the deviations of each data with respect to the average of the respective treatment, the normality of the same was assumed (13).

\section{RESULTS AND DISCUSSION}

\section{Soil water content and Cone index}

The differences in the soil water content (SWC) were generally not significant between the different depth intervals on the day the traffic treatments were imposed on each sample (table 3). Therefore, the variations in CI in depth were not due to the SWC. This suggested that the cone index was a reliable indicator of the soil compaction degree as a function of the traffic treatment.

Table 3. Soil water content $(\mathrm{w} / \mathrm{w})$ at the traffic moment.

Tabla 3. Contenido de agua del suelo $(\mathrm{m} / \mathrm{m})$ al momento del tráfico.

\begin{tabular}{|l|l|}
\hline \multicolumn{2}{|c|}{ Soil water content (w/w) } \\
\hline Depth range levels (mm) \\
\hline $0-150$ & $21.1 \pm 1.27 \mathrm{a}$ \\
$150-300$ & $22.3 \pm 1.24 \mathrm{a}$ \\
$300-450$ & $22.9 \pm 1.33 \mathrm{a}$ \\
\hline
\end{tabular}

Average values \pm standard deviation $(\mathrm{n}=25)$.

Values with different letters are significantly different at each depth ( $\mathrm{P}<0.01$ Duncan's multiple range test).

Valores medios \pm desviación estándar $(n=25)$.

Los valores con letras diferentes son significativamente diferentes para cada profundidad ( $\mathrm{P}<0,01$ Prueba de rango múltiple de Duncan). 
According to table 3 (page 113), the SWC at the traffic moment was $21.1 \%$ in the topsoil (0-150 mm), $22.3 \%$ at $150-300 \mathrm{~mm}$ and $22.9 \%$ at $300-450 \mathrm{~mm}$. According to this, the SWC values at the time of testing were 0.9 points lower than the Proctor value $(22.0 \%)$ in the 0 to $150 \mathrm{~mm}$ depth range. The SWC values were also 1.6 points lower than the Proctor value $(23.9 \%)$ in the 150 to $300 \mathrm{~mm}$ depth range and 0.5 points minor $(23.4 \%)$ in the 300 to $450 \mathrm{~mm}$ depth range respectively. From the mentioned Proctor values, it can be inferred that the SWC, at the traffic moment, was close to the value that can produce maximum soil compaction. This situation is very important when analyzing the compaction results due to traffic because it was the worst moment to carry out the traffic. However, these are normal values of soil water content when the farmers perform most of the agricultural work (7).

It is important to note that the typical tillage depths in Argentina are approximately $200 \mathrm{~mm}$. Therefore, the Ap horizon is considered, in this experiment, 0-200 $\mathrm{mm}$ as the topsoil layer. The subsoil can be defined as the soil below the tillage layer (6).

The cone index data gave a clear indication of the initial soil condition in each treatment (table 4). The CI values reached their maximum at $200 \mathrm{~mm}$ depth $(\approx 2653 \mathrm{kPa})$ in the topsoil of the control plot. On the other hand, in the subsoil the maximum CI value was found at $450 \mathrm{~mm}$ depth $(\approx 3247 \mathrm{kPa})$.

Table 4. Average $(n=25)$ cone index values $(\mathrm{kPa})$ for the traffic treatments.

Tabla 4. Valores medios $(n=25)$ de índice de cono $(\mathrm{kPa})$ para los tratamientos de tráfico.

Values with different letters (horizontally) are significantly different at each depth $(\mathrm{P}<0.01$ Duncan's multiple range test).

Los valores con letras diferentes (horizontalmente) son significativamente diferentes para cada profundidad $(\mathrm{P}<0,01$ Prueba de rango múltiple de Duncan).

\begin{tabular}{|c|c|c|c|c|c|}
\hline $\begin{array}{c}\text { Depth } \\
\text { (mm) }\end{array}$ & $\begin{array}{c}\text { Control plot } \\
\text { (unloosened } \\
\text { Soil) }\end{array}$ & $\begin{array}{c}\text { FWA } \\
\text { Tractor }\end{array}$ & $\begin{array}{c}\text { Grain } \\
\text { chaser }\end{array}$ & $\begin{array}{c}\text { Combine } \\
\text { harvester }\end{array}$ & Sprayer \\
\hline \multicolumn{5}{|c|}{ Topsoil (0 to 200 mm) } \\
\hline 0 & $1507 \mathrm{a}$ & $1723 \mathrm{~b}$ & $1888 \mathrm{c}$ & $2200 \mathrm{~d}$ & $2433 \mathrm{e}$ \\
\hline 25 & $1682 \mathrm{a}$ & $1801 \mathrm{~b}$ & $1980 \mathrm{c}$ & $2256 \mathrm{~d}$ & $2525 \mathrm{e}$ \\
\hline 50 & $1790 \mathrm{a}$ & $1904 \mathrm{~b}$ & $2150 \mathrm{c}$ & $2334 \mathrm{~d}$ & $2622 \mathrm{e}$ \\
\hline 75 & $1880 \mathrm{a}$ & $2000 \mathrm{~b}$ & $2187 \mathrm{c}$ & $2369 \mathrm{~d}$ & $2740 \mathrm{e}$ \\
\hline 100 & $2132 \mathrm{a}$ & $2250 \mathrm{~b}$ & $2530 \mathrm{c}$ & $2698 \mathrm{~d}$ & $2888 \mathrm{e}$ \\
\hline 125 & $2167 \mathrm{a}$ & $2360 \mathrm{~b}$ & $2563 \mathrm{c}$ & $2793 \mathrm{~d}$ & $2951 \mathrm{e}$ \\
\hline 150 & $2250 \mathrm{a}$ & $2450 \mathrm{~b}$ & $2610 \mathrm{c}$ & $2804 \mathrm{~d}$ & $2983 \mathrm{e}$ \\
\hline 175 & $2369 \mathrm{a}$ & $2556 \mathrm{~b}$ & $2690 \mathrm{c}$ & $2841 \mathrm{~d}$ & $2990 \mathrm{e}$ \\
\hline 200 & $2653 \mathrm{a}$ & $2700 \mathrm{a}$ & $2802 \mathrm{c}$ & $2959 \mathrm{~d}$ & $3190 \mathrm{e}$ \\
\hline & & Subsoil (>200 mm) & & \\
\hline 225 & $2800 \mathrm{a}$ & $2900 \mathrm{a}$ & $3400 \mathrm{c}$ & $3234 \mathrm{~b}$ & $3200 \mathrm{~b}$ \\
\hline 250 & $2901 \mathrm{a}$ & $2910 \mathrm{a}$ & $3457 \mathrm{c}$ & $3272 \mathrm{~b}$ & $3196 \mathrm{~b}$ \\
\hline 275 & $2920 \mathrm{a}$ & $2940 \mathrm{a}$ & $3560 \mathrm{c}$ & $3230 \mathrm{~b}$ & $3180 \mathrm{~b}$ \\
\hline 300 & $2956 \mathrm{a}$ & $2990 \mathrm{a}$ & $3601 \mathrm{c}$ & $3241 \mathrm{~b}$ & $3200 \mathrm{~b}$ \\
\hline 325 & $2980 \mathrm{a}$ & $3010 \mathrm{a}$ & $3656 \mathrm{c}$ & $3287 \mathrm{~b}$ & $3210 \mathrm{~b}$ \\
\hline 350 & $3001 \mathrm{a}$ & $3078 \mathrm{a}$ & $3678 \mathrm{c}$ & $3352 \mathrm{~b}$ & $3265 \mathrm{~b}$ \\
\hline 375 & $3100 \mathrm{a}$ & $3140 \mathrm{a}$ & $3689 \mathrm{c}$ & $3390 \mathrm{~b}$ & $3300 \mathrm{~b}$ \\
\hline 400 & $3145 \mathrm{a}$ & $3195 \mathrm{a}$ & $3699 \mathrm{c}$ & $3410 \mathrm{~b}$ & $3309 \mathrm{~b}$ \\
\hline 425 & $3201 \mathrm{a}$ & $3233 \mathrm{a}$ & $3710 \mathrm{c}$ & $3429 \mathrm{~b}$ & $3321 \mathrm{~b}$ \\
\hline 450 & $3247 \mathrm{a}$ & $3276 \mathrm{a}$ & $3745 \mathrm{c}$ & $3503 \mathrm{~b}$ & $3400 \mathrm{~b}$ \\
\hline
\end{tabular}

These CI values in the control plot could tend to retard root growth in situations of low soil water content. However, there could also be an improvement in the soil bearing capacity that could moderate, together with the crop harvest residue on the soil surface, the negative effects of the agricultural traffic.

Besides, the treatments with the highest average ground pressure (combine harvester (>135 kPa) and sprayer (> 233)) caused CI values exceeding $2000 \mathrm{kPa}$ from the $0 \mathrm{~mm}$ depth level. Botta et al. (2018b) suggested that this value is a limitation, not only of the seed emergence, but also for the root development. It is important to mention that Threadgill (1982) 
indicates that $\mathrm{CI}$ values above $1500 \mathrm{kPa}$ decrease root development, while CI values of 2100 to $2500 \mathrm{kPa}$ can stop root growth.

For these treatments (the combine harvester and the sprayer), the $\mathrm{CI}$ values were higher than $2500 \mathrm{KPa}$ in the subsoil, (300 $\mathrm{mm}$ to $450 \mathrm{~mm}$ ), denoting over-compaction. Also for these treatments, the CI exceeded the critical soil strength values, above which root growth and expansion are significantly affected (e.g., 11, 14, 18, 19).

According to Botta et al. (2019), subsoil compaction is due to several factors. These factors are the high wheel load, the tyre ground pressure, and the machinery traffic intensity used for crop protection and harvest operations, rather than for seeding. Special emphasis should be placed on the impact of these operations when performed on wet clayey soils or with high tyres inflation pressure (between 140 and $218 \mathrm{kPa}$ ). The induced soil compaction within this layer is cumulative, since no conventional tillage is performed at that depth.

Finally, the FWA tractor showed significant differences (in CI values) with respect to the control plot up to a depth of $175 \mathrm{~mm}(P<0.01)$. This indicated an increased subsoil carrying capacity compared to topsoil.

The rut depth measurements were significantly different for the sprayer machine and the combine harvester compared to the FWA tractor and the grain chaser $(P<0.01)$. The sprayer and the combine harvester showed significantly higher RD values than the FWA tractor and the grain chaser. This was due to the high tyre ground pressure, being 23.7 and $20.1 \mathrm{~mm}$ for the sprayer and the combine harvester respectively (table 5). It should be noted that, despite the high tyre ground pressures values, the RD did not exceed $25 \mathrm{~mm}$ in any treatment. This probably occurred because that $\mathrm{CI}$ in the control plot already exceeded $2132 \mathrm{kPa}$ at $100 \mathrm{~mm}$ depth. This indicated the high level of previous compaction it had due to the application of a continuous no-tillage cropping.

Table 5. Average values $(\mathrm{n}=20)$ of rut depth $(\mathrm{mm})$ in the four traffic treatments.

Tabla 5. Valores medios $(\mathrm{n}=20)$ de profundidad de huella $(\mathrm{mm})$ en los cuatro tratamientos de tráfico.

\begin{tabular}{|c|c|c|c|}
\hline Sprayer & Combine Harvester & FWA Tractor & Grain Chaser \\
\hline $23.7 \mathrm{a}$ & $20.1 \mathrm{a}$ & $12.1 \mathrm{~b}$ & $15.7 \mathrm{c}$ \\
\hline \multicolumn{4}{|c}{} \\
Values with different letters (horizontally) are significantly different at each depth ( $\mathrm{P}<0.01$ ) Duncan's \\
multiple range test).
\end{tabular}

As for the RD, Table 5 shows that the sprayer rut depth is $12.98 \%$ greater than the combine harvester rut depth. This should be taken into account even though there are no significant differences between the combine harvester rut depth and the sprayer rut depth. The results are in agreement with the results of Botta et al. (2019) and Raper (2005). These autors also indicated that the soil surface was the most vulnerable layer to both compression and displacement from the passage of the agricultural machinery.

In addition, there was a clear correlation (statistically significant) between RD and soil compaction $\left(R^{2}\right.$ values were between 0.90 and 0.96 for $\mathrm{CI}$ ) in the deeper subsoil (200 to $450 \mathrm{~mm}$ ) for the combine harvester. This correlation was not clear $\left(R^{2}\right.$ values were between 0.04 and 0.07 for $\mathrm{CI})[P<0.01])$ in the case of the grain chaser. In this treatment, the mean values of GCP per tyre and wheel load did not exceed $78.7 \mathrm{kPa}$ and $49 \mathrm{kN}$, respectively.

The measurements of TA $\left(\mathrm{m}^{2} \mathrm{ha}^{-1}\right)$ were significantly different for all traffic treatments (table 6, page 116). The smallest TA corresponds to the sprayer. This is easy to understand due to the wide case of the tyre that these kinds of machine use. However, despite this, it is important to remember that the tyre ground pressure RD was the highest for this machine. The average RD value was $23.7 \mathrm{~mm}$. From this it can be noted that the tyre ground pressure exceeded $200 \mathrm{kPa}$ in both axes. 
Table 6. Average values $(n=20)$ of trampled area $\left(\mathrm{m}^{2} \mathrm{ha}^{-1}\right)$ in the four traffic treatments. Tabla 6. Valores medios $(\mathrm{n}=20)$ de área pisada $\left(\mathrm{m}^{2} \mathrm{ha}^{-1}\right)$ en los cuatro tratamientos de tráfico.

\begin{tabular}{|c|c|c|c|}
\hline Sprayer & Combine Harvester & FWA Tractor $*$ & $\begin{array}{c}\text { Tractor and Grain } \\
\text { Chaser }\end{array}$ \\
\hline $300.1 \mathrm{a}$ & $1713.6 \mathrm{c}$ & $1777.3 \mathrm{~d}$ & $373.3 \mathrm{~b}$ \\
\hline
\end{tabular}

Values with different letters (horizontally) are significantly different at each depth $(\mathrm{P}<0.01)$ Duncan's multiple range test). * FWA Tractor and planter wheeled on the same track.

Los valores con letras diferentes (horizontalmente) son significativamente diferentes para cada profundidad (P $<0,01$ Prueba de rango múltiple de Duncan).

In the case of the FWA tractor, it should be noted that it produced a high trampled area per hectare. The value shown in table 6 seems high. Nevertheless, the trampled area produced by this tractor when it traffics on the same track as the grain planter caused the trampled area to be masked in that of the grain planter. This is very important for the annual traffic planning, as well as the track alignment of the machinery used as far as possible.

Finally, it was shown that when the machinery load increases on soils with high bearing capacity (soils under a long-term no-tillage system), the subsoil compaction problems increase. Hence, these data support the hypothesis. This hypothesis includes: In soils under a continuous no-tillage system, compaction mitigation may be achieved by operating with low-loads, low contact pressure from tyres and reducing the trampled area.

\section{Conclusions}

Given the experimental conditions of this study, the following conclusions can be drawn:

1) The area trampled by the agricultural machinery can be reduced by making a previous planning of the traffic as well as an adequate regulation of the wheel track width. In addition, track alignment of the agricultural machines can alleviate the compaction produced by the passage of the wheels with high load.

2) Soil under a no-tillage system does not limit topsoil and subsoil compaction when wheeled by tyres with ground pressures greater than $77.6 \mathrm{kPa}$.

3) Also, in relation to the machinery weight, it was established that agricultural machinery with a minimum weight of $79.8 \mathrm{kN}$ (FWA tractor) can produce subsoil compaction with a single pass.

\section{REFERENCES}

1. Antille, D. L.; Bennett, J. M.; Jensen, T. 2016. Soil compaction and controlled traffic considerations in Australian cotton-farming systems. Crop \& Pasture Science. 67: 1-28 doi: 10.1071/ CP15097

2. Antille, D. L.; Peets, S.; Galambošová, J.; Botta, G. F.; Rataj, V.; Macak, M.; Tullberg, J. N.; Chamen, W. C. T.; White, D. R.; Misiewicz, P. A.; Hargreaves, P. R.; Bienvenido, J. F.; Godwin, R. J. 2019. Review: Soil compaction and controlled traffic farming in arable and grass cropping systems. Agronomy Research, 17(3): 653-682. doi.org/10.15159/AR.19.133

3. ASABE. 2013. EP542: Procedures for using and reporting data obtained with the soil cone penetrometer. St. Joseph, MI: American Society of Agricultural and Biological Engineers.

4. ASAE Standard. 1992. Terminology and definitions for soil tillage and soil tool relationships Engineering Practice. EP291. American Society of Agricultural Engineering. Vol. 2: 611 p.

5. ASTM. 1992. Annual Book of ASTM Standards. American Society for Testing and Materials. Philadelphia. PA.

6. Botta, G. F.; Jorajuria, D.; Draghi, L. 2002. Influence of the axle load, tyre size and configuration, on the compaction of a freshly tilled clayey soil. J. of Terr. 39(1): 47-54. doi.org/10.1016/ S0022-4898(02)00003-4

7. Botta, G. F.; Jorajuria, D.; Balbuena, R.; Rosatto, H. 2004. Mechanical and cropping behaviour of direct drilled soil under different traffic intensities: Effect on soybean (Glycine max L.) yields. Soil Till. Res. 78: 53-58. doi:10.1016/j.still.2004.01.004

8. Botta, G. F.; Vazquez, J.; Tolon-Becera, A.; Balbuena, R.; Stadler, S. 2012. Soil compaction distribution under land clearing in calden (Prosopis Caldenia Burkart) forest in Argentinean pampas. Soil Till. Res. 119: 70-75. doi:10.1016/j.still.2011.12.007 
9. Botta, G. F.; Tolón-Becerra, A.; Lastra-bravo, X.; Hidalgo, R.; Rivero, D.; Agnes, D. 2015. Alternatives for handling rice (Oryza sativa L.) straw to favor its decomposition in direct sowing systems and their incidence on soil compaction. Geoderma. 239-240: 213-222. doi: 10.1016/j. geoderma.2014.10.021

10. Botta, G. F.; Tolon-Becerra, A.; Bienvenido, F.; Rivero, E. R. D.; Laureda, D.; Contessotto, E. E.; Fonterosa, A.; Agnes, D. 2018a. Traffic of harvester combines: effect on maizeyields (Zea Mays L.) and soil compaction under direct sowing system. Revista de la Facultad de Ciencias Agrarias. Universidad Nacional de Cuyo. Mendoza. Argentina. 50(1): 85-100.

11. Botta, G. F.; Tolón-Becerra, A.; Bienvenido, F.; Rivero, D; Laureda, A.; Ezquerra-Canalejo, A.; Contessotto, E. E. 2018b. Sunflower (Helianthus annuus L.) harvest: Tractor and grain chaser traffic effects on soil compaction and crop yields. Land Degrad Dev. 29: 4252-4261. doi: $10.1002 /$ ldr.3181

12. Botta, G. F.; Bienvenido, J. F.; Antille, D. L.; Rivero, E. R. D.; Contessotto, E. E.; Ghelfi, D. G.; Nistal, A. I.; Pelizzari, F. M. 2019. Effect of traffic with a light-weight tractor on physical properties of an Aridisol soil in Almeria, Spain. Revista de la Facultad de Ciencias Agrarias. Universidad Nacional de Cuyo. Mendoza. Argentina. 51(2): 270-279.

13. Botta, G. F.; Antille, D. L.; Bienvenido, F.; Rivero, D.; Avila-Pedraza, E. A., Contessotto, E. E.; Ghelfi, D. G.; Nistal, A. I.; Pelizzari, F. M.; Rocha-Meneses, L.; Ezquerra-Canalejo, A. 2020. Effect of cattle trampling and farm machinery traffic on soil compaction of an Entic Haplustoll in a semiarid region of Argentina. Agronomy Research 18(S2): 1163-1176. https://doi. org/10.15159/ar.20.063

14. Canarache, A.; Colibas, I.; Colibas, M.; Horobeanu, I.; Patru, V.; Simota, H.; Trandafirescu, T. 1984. Effect of induced compaction by wheel traffic on soil physical properties and yield of maize in Romania. Soil Till. Res. 4(2): 199-213.

15. Contessotto, E. E.; Botta, G. F. 2020. Power and draft required by chisel plow on soils under no- tillage in the Argentinean flat Pampas. Revista de la Facultad de Ciencias Agrarias. Universidad Nacional de Cuyo. Mendoza. Argentina. 52(2): 102-110.

16. European Commission (2006). Proposal for a directive of the European Parliament and of the Council establishing a framework for the protection of soil and amending Directive 2004/35/EC. COM. 232 final. Brussel: Europese Commissie.

17. Håkansson, I. 1987. Long term effects of modern technology on productivity of arable land. K. Skogs-o. Lantbr. Akad. Tidskr. 126: 35-40.

18. Håkansson, I.; Reeder, R. C. 1994. Subsoil compaction by vehicles with high axle load extent, persistence and crop response. Soil Tillage Res. 29: 277-304.

19. Hidalgo, R.; Botta, G. F.; Tolón-Becerra, A.; Pozzolo, O.; Dominguez, F.; Serafini, E. 2014. Rastrojo de arroz (Oryza sativa L.) en sistemas de siembra directa: alternativas de manejo. Revista de la Facultad de Ciencias Agrarias. Universidad Nacional de Cuyo. 46(2): 163-175.

20. Maineri, D. 2020. Pisoteo del suelo por el tráfico de la maquinaria agrícola en suelos bajo labranza convencional. Trabajo Final de graduación para optar al título de Ingeniero Agrónomo. Biblioteca. UNLuján. Luján. Argentina. 24 p.

21. Raper, R. L. 2005. Agricultural traffic impacts on soil. Journal of Terramechanics. 42: 259-280.doi. org/10.1016/j.jterra.2004.10.010

22. Soil Survey Staff. 2014. Keys to Soil Taxonomy, $12^{\text {th }}$ ed. USDA-Natural Resources Conservation Service. Washington. DC.

23. Threadgill, E. 1982. Residual tillage effects as determined by cone index. Trans. ASAE. 25: 859, $863,867$.

24. Tolon-Becerra, A.; Lastra-Bravo, X.; Botta, G. F.; Tourn, M.; Linares, P.; Ressia, J. M; Balbuena, R. H. 2011. Traffic effect on soil compaction and yields of wheat in Spain. Spanish Journal of Agricultural Research. 9(2): 395-403. doi:10.5424/sjar/20110902-235-10

25. Tullberg, J. N. 2000. Wheel traffic effects on tillage draught. Journal of Agricultural Engineering Research. 75(2): 375-382. doi.org/10.1006/jaer.1999.0516

26. Tullberg, J. N.; Yule, D. F.; McGarry, D. 2007. Controlled traffic farming-from research to adoption in Australia. Soil Tillage Res. 97: 272-281. doi.org/10.1016/j.still.2007.09.007

27. Vermeulen, G. D.; Mosquera, J. 2009. Soil, crop and emission responses to seasonal-controlled traffic in organic vegetable farming on loam soil. Soil Till. Res. 102: 126-134. doi:10.1016/j. still.2008.08.008

\section{ACKNOWLEDGEMENTS}

This work was supported by grants to Technology Department National University of Luján (Project T088 UNLu.) and F.A. UNLPam (Project (I- 153/19 FA). 